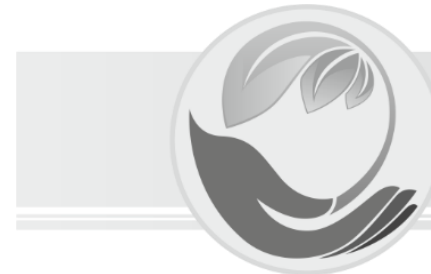

Удк 631.4/631.5
Інтенсивні та екологічно ощадні технології рослинництва Intensive and ecosaving techniques in crop production

\title{
Дослідження та моделювання показників в різних видах обробітку ґрунту під сільськогосподарські культури для умов чорноземних ґрунтів України
}

\author{
О.В. Таценко ${ }^{1}$, А.В. Мартинюк ${ }^{2}$, В.С. Курской ${ }^{3}$ \\ 1 Сумський національний аграрний університет (м. Суми, Україна) \\ 2, 3 Хмельницький національний університет (м. Хмельницький, Україна) \\ email:1 alextatsenko@ukr.net, ${ }^{2}$ av.mart@ukr.net, ${ }^{3}$ vk702713@gmail.com \\ ORCID: ${ }^{1}$ 0000-0003-1762-8219, ${ }^{2}$ 0000-0001-8277-1308, ${ }^{3}$ 0000-0002-3929-884X
}

\begin{abstract}
У технологіях вирощування сільськогосподарських культур найбільші резерви енергозбереження та підвищення продуктивності сільськогосподарських культур мають способи обробітку ґрунту. Сучасні тенденції сільськогосподарського виробництва потребують обґрунтування, запровадження і використання раціональних сучасних ґрунтообробних знарядь та вдосконалення існуючих технологічних процесів обробітку ґрунту.

Проаналізовано останні дослідження та публікації напрямків підвищення ефективності обробітку ґрунту під сільськогосподарські культури та використання технічних засобів для їх реалізації в умовах чорноземних ґрунтів України.

Проведено наукові дослідження та моделювання зміни показника твердості ґрунту і енергетичних витрат в різних способах та видах обробітку ґрунту під сільськогосподарські культури для умов чорноземних ґрунтів України. Процес дослідження та моделювання енергетичних витрат і твердості ґрунту проводився на основі зміни показників глибини обробітку, виду обробітку і типу технічних засобів, які реалізують технологічний процес обробітку ґрунту під сільськогосподарські культури.

В статті наведені результати дослідження впливу технологічних процесів обробітку ґрунту на енергетичні витрати та твердість ґрунту в умовах стаціонарного досліду дослідного поля для різних варіантів обробітку ґрунту в технологіях вирощування сільськогосподарських культур.

При дослідженнях, які проводились відповідно до розробленої програми та методики, визначались показники якості виконання процесу обробітку ґрунту та витрати палива в залежності від виду і глибини обробітку ґрунту.

Моделювання математичних залежностей зміни показників досліджувались в 3D проекціях. Реалізація 3D моделювання для різних варіантів технологічного процесу обробітку ґрунту під сільськогосподарські культури проводилось в програмному пакеті Statistica.

Зміна виду обробітку ґрунту та збільшення глибини обробітку ґрунту обумовлює покращення якості підготовки ґрунту та збільшення витрат палива.
\end{abstract}

Ключові слова: технологічний процес, обробіток грунту, види обробітку грунту, технічні засоби, глибина обробітку, твердість, витрата палива, дослідження, моделювання.

Постановка проблеми та ії актуальність. Традиційні технології виробництва рослинницької продукції без економного використання ресурсів $\epsilon$, зазвичай, багатовитратними. А це $є$ головною причиною високої собівартості продукції, її низької конкурентоспроможності на ринках, а також стримуючий фактор ефективного розвитку сільськогосподарського виробництва. Тому робота по розробці і впровадженню технологій, які забезпечують елементи ресурсозбереження є одним із основних напрямків ефрективного виробництва конкурентоздатної сільськогосподарської продукції.

У загальних витратах ресурсів, що використовуються при вирощуванні сільськогосподарських культур, близько 40\% припадає на долю енергетичних, тому скорочення їх витрат набуває зараз основного значення. 
У технологіях вирощування сільськогосподарських культур найбільші резерви енергозбереження мають способи обробітку ґрунту із запровадженням і обґрунтуванням мінімально раціональних шляхом використання сучасних ґрунтообробних знарядь та вдосконалення вже відомих до цього.

Метою досліджень по мінімалізації обробітку ґрунту є вивчення сукупності агрономічних, технічних і економічних показників, які впливають на кількість виробленої продукції сільськогосподарських культур та затрати на її отримання.

В зв'язку з цим науковцями ведуться роботи по дослідженню систем обробітку ґрунту і технічних засобів для їх реалізації, в розрізі скорочення витрат енергетичних ресурсів та поліпшення якості виконання технологічного процесу.

Аналіз останніх досліджень та публікацій. Багаторічний досвід показує, що різні сільськогосподарські культури досить вимогливі до якості якості і виду основного обробітку ґрунту. Тому у збільшенні виходу продукціі сільськогосподарських культур велика роль належить розробці і впровадженню ефективних агротехнічних прийомів і технічних засобів для обробітку ґрунту.

Результати досліджень доводять, що переущільнення ґрунту погіршує його структуру, водопроникність, мікрорельєф, умови проведення подальших польових робіт, знижує ефективність дії мінеральних добрив, підвищує тяговий опір грунтообробних машин, збільшує затрати енергії і витрату пального на одиницю оброблюваної площі до $20 \%$. За даними науково-дослідного центру в Браншвейг-Фолькенроде, на 1 га посівів сільськогосподарських культур за сезон припадає понад 50 км проходів сільськогосподарської техніки, що на $37 \%$ більше, ніж у зерновому господарстві, що призводить до зниження врожайності сільськогосподарських культур на 22\%.

Проведені дослідження показують, що розподіл затрат на обробіток ґрунту у Лісостеповій зоні України показує, що на нього припадає $40 . .50 \%$ енергетичних затрат і $25 \%$ трудових від всього обсягу робіт при вирощуванні сільськогосподарських культур.

Виходячи із наведеного, ми бачимо, що виникає необхідність розробки нових ефективних систем обробітку ґрунту або їх вдосконалення. Така потреба викликана покращенням властивостей ґрунту, збереження гумусного балансу та родючості ґрунту, зменшенням витрат вологи і поживних речовин із ґрунту, захистом ґрунту від різних видів ерозії.

Аналіз даних технологій також показує, що запізнення з проведенням ранньовесняних механізованих робіт і сівби, через їх велику кількість і низьку продуктивність машинних агрегатів, призводить до скорочення вегетаційного періоду і, як наслідок, - до зниження урожайності основної продукції сільськогосподарських культур. На даний час при вирощуванні сільськогосподарських культур традиційно застосовують ряд технологій, що мають визначену направленість і які відрізняються одна від другої деякими прийомами, відповідно до конкретних грунтово-кліматичних умов господарств [1, 2].

В результаті проведених досліджень та аналізу характеру розподілу затрат енергії по різних видах обробітку чорноземних ґрунтів в Лісостепній зоні України отримано, що на обробіток ґрунту витрачається близько 40 - 50\% питомих затрат енергії.

Одним із основних способів зниження енергетичних затрат $€$ мінімалізація глибини обробітку ґрунту та зменшення кількості проходів машинних агрегатів, через використання комплексних та комбінованих агрегатів. Наведені способи стають основою по удосконаленню систем обробітку ґрунту.

Аналіз тенденцій розвитку технологій і технічних засобів для вирощування сільськогосподарських культур та дає можливість говорити про підстави для розробки і випробування системи машин для підвищення продуктивності і зниження енергетичних затрат.

Так у країнах Західної Європи широко впроваджена сучасна технологія вирощування сільськогосподарських культур з використанням комплексних та комбінованих робочих машин для проведення механізованих технологічних процесів. Сільськогосподарські підприємства Німеччини при вирощуванні сільськогосподарських культур на 1 га витрачають 15 - 20\% енергетичних ресурсів менше ніж вітчизняні.

Вивчення процесу вирощування сільськогосподарських культур 3 мінімальним обробітком ґрунту проводиться різними науковими установами і широко впроваджується передовими господарствами, що вирощують основні сільськогосподарські культури [3].

Механіко-технологічні властивості грунтів мають великий вплив на якісні показники проведення обробітку грунту під сільськогосподарські культури та енергетичні витрати технічних засобів, які його реалізують у виробничих умовах, в тому числі і на чорноземних грунтах України [4].

В наукових публікаціях дане питання дослідження показників в різних видах обробітку ґрунту під сільськогосподарські культури для умов чорноземних ґрунтів України було частково розглянуто для обробітку грунту під цукрові буряки з дослідженням та моделюванням техніко-експлуатаційних показників роботи машинних агрегатів [5], твердості грунту [6], урожайності (продуктивності) основної продукції [7] та витрат палива [8] для різних видів та способів обробітку грунту з використанням типових грунтообробних робочих машин. Ці 
наукові публікації дають можливість говорити, що питання дослідження обробітку грунту є актуальним та важливим для впровадження сучасних агротехнічних прийомів та видів робочих органів.

Отже, результати вирощування основних сільськогосподарських культур у передових господарствах та висновки науково-виробничих установ свідчать про те, що мінімалізація обробітку ґрунту під сільськогосподарські культури дає можливість проведення механізованих польових робіт у більш стислі та строки, що приводить до збільшення вегетаційного періоду і підвищення урожайності основної продукції с/г культур, а також до скорочення витрат енергетичних ресурсів.

Формулювання мети роботи (постановка задачі дослідження). Розв'язання цих задач можливе за рахунок вибору раціональної системи операцій по обробітку ґрунту та чинних технічних засобів (робочих машин та інше) ставлячи в основу та використовуючи при цьому критерій ефрективності енергетичних затрат та якість обробітку грунту.

Метою роботи $є$ пошук напрямків підвищення ефрективності обробітку ґрунту під сільськогосподарські культури та використання технічних засобів для їх реалізації в умовах лівобережного Лісостепу України через зменшення енергетичних витрат.

Для досягнення поставленої мети необхідно вирішити наступну науково-практичну задачу, яка базується на визначенні твердості ґрунту, глибини обробітку та питомих витрат палива машинними агрегатами в різних видах обробітку ґрунту під сільськогосподарські культури.

Викладення основного матеріалу дослідження 3 обґрунтуванням отриманих наукових результатів. 3 метою дослідження впливу технологічних процесів обробітку ґрунту на енергетичні витрати та твердість ґрунту в умовах стаціонарного досліду дослідного поля проводилися дослідження різних варіантів обробітку ґрунту в технологіях вирощування сільськогосподарських культур, які базуються на наступних способах основного обробітку ґрунту: оранка на глибину 25...27 см (варіант 1), плоскорізний (чизельний обробіток) на 14...16 см (варіант 2), дискування на глибину 10...12 см (варіант 3) та дискування на глибину 4...6 см (варіант 4). Варіанти обробітку ґрунту були закладені з використанням енергетичного засобу (трактора) МТ3-82 та наступних ґрунтообробних знарядь: глибокий полицевий (оранка на глибину 25...27 см) - агрегатом у складі з навісним плугом ПЛН-3-35; плоскорізний (чизельний) - агрегатом КЛД-2,0; дискування на глибину 10...12 см - дисковим агрегатом АГ-2,4; дискування на глибину $4 . . .6$ см - дисковим агрегатом АГ-2,4. Схема досліду представлена в таблиці 1.

Результати дослідження. 3 метою дослідження впливу технологічних процесів обробітку ґрунту було проведено дослідження таких показників, як твердість ґрунту, витрати палива і отриманої врожайності в залежності від глибини обробітку ґрунту під сільськогосподарські культури. Отримані результати досліджень занесено в таблицю 2.

Таблиця 1. Схема дослідження впливу технологічних процесів обробітку ґрунту на енергетичні витрати та твердість ґрунту

\begin{tabular}{|c|c|c|c|}
\hline 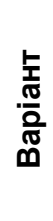 & $\begin{array}{l}\text { Вид обробі- } \\
\text { тку ґрунту }\end{array}$ & 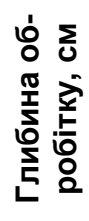 & Агрегат \\
\hline 1 & Оранка & 27 & МТЗ-82+ПЛН-3-35 \\
\hline 2 & $\begin{array}{l}\text { Плоскорізний } \\
\text { (чизельний) }\end{array}$ & 16 & МТЗ-82+Клд-2,0 \\
\hline 3 & Дискування & 12 & MT3-82+AГ-2,4 \\
\hline 4 & Дискування & 6 & MT3-82+AГ-2,4 \\
\hline
\end{tabular}

Таблиця 2. Результати досліджень впливу технологічних процесів обробітку ґрунту на енергетичні витрати та твердість ґрунту

\begin{tabular}{|c|c|c|c|c|}
\hline \multirow[b]{2}{*}{$\begin{array}{l}\frac{0}{5} \\
\frac{0}{T} \\
\frac{0}{0} \\
\frac{0}{0} \\
\text { 음 }\end{array}$} & \multirow[b]{2}{*}{ № } & \multicolumn{3}{|c|}{ Показники } \\
\hline & & 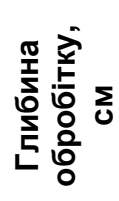 & 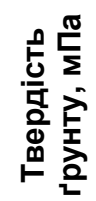 & 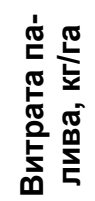 \\
\hline \multirow{4}{*}{1} & 1 & 6 & 2,843 & 4,84 \\
\hline & 2 & 12 & 2,835 & 6,89 \\
\hline & 3 & 16 & 2,765 & 8,92 \\
\hline & 4 & 27 & 2,695 & 17,69 \\
\hline \multirow{4}{*}{2} & 1 & 6 & 2,605 & 4,96 \\
\hline & 2 & 12 & 2,578 & 7,23 \\
\hline & 3 & 16 & 2,497 & 9,14 \\
\hline & 4 & 27 & 2,405 & 18,71 \\
\hline \multirow{4}{*}{3} & 1 & 6 & 2,294 & 5,1 \\
\hline & 2 & 12 & 2,884 & 7,44 \\
\hline & 3 & 16 & 2,797 & 9,31 \\
\hline & 4 & 27 & 2.712 & 18.06 \\
\hline
\end{tabular}

Моделювання математичних залежностей зміни показників, які досліджувались в 3D проекціях для реалізації різних варіантів технологічного процесу обробітку ґрунту під сільськогосподарські культури проводилось в програмному пакеті Statistica 6.0 та згідно рекомендацій по вирішенню практичних задач методами комп'ютерного моделювання $[9,10]$. Результати 3D моделювання представлені на Рис.1, Рис. 2 та Рис. 3. 
Витрати палива, кг/га -

Функція твердості грунту, мПа

і глибини обробітку, см.

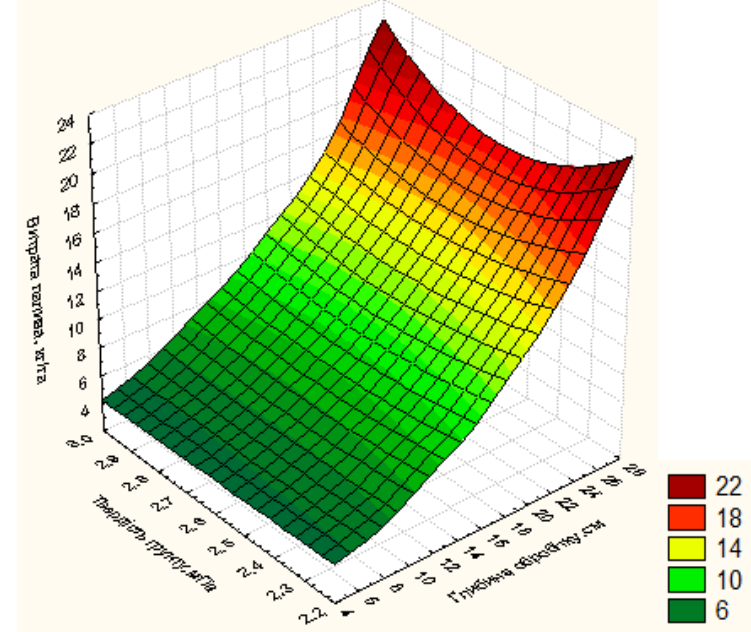

Рис.1. Зміна витрати палива в залежності від зміни твердості грунту та глибини обробітку грунту

Витрати палива зменшується із мінімалізацією глибини обробітку ґрунту та вар'юванням середньої твердості в посівах за вегетаційний період в межах 2,2 … 2,9 мПа в різних видах обробітку ґрунту під сільськогосподарські культури.

Твердість ґрунту, мПа Функія глибини обробітку, см і витрат палива, кг/га.

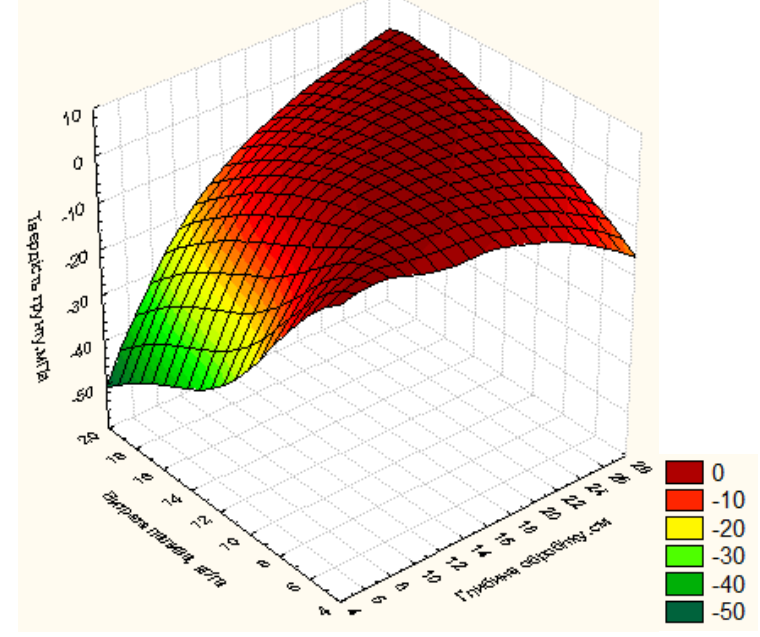

Рис.2. Зміна твердості грунту в залежності від зміни глибини обробітку грунту та витрати палива

Середня твердість ґрунту за вегетаційний період зростає із збільшенням глибини обробітку і витрат палива в різних видах обробітку ґрунту при вирощуванні цукрових буряків.
Глибина обробітку ґрунту, см -

Функція твердості грунту, мПа і витрат палива, кг/га

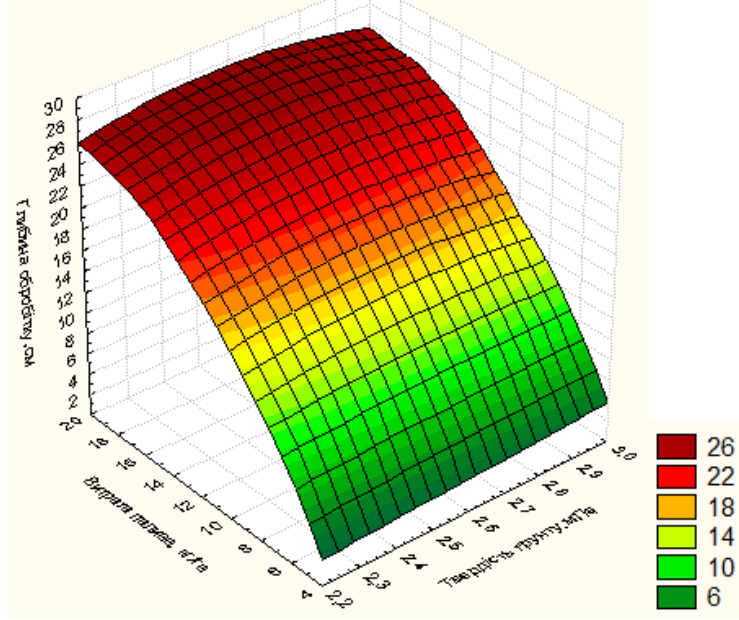

Рис.3. Зміна глибини обробітку в залежності від зміни витрат палива та твердості грунту

Збільшення глибини обробітку ґрунту обумовлюється збільшенням витрат палива при вар'юванні середньої твердості в посівах сільськогосподарських культур за вегетаційний період в межах 2,2 … 2,9 мПа при різних видах обробітку ґрунту.

Аналізуючи отримані результати дослідження твердості ґрунту в залежності від глибини в різних схемах (оранка, плоскорізний обробіток та дискування на глибину 6 см і 12 см) можно зробити висновок, що закон зміни контролюємого показника описується поліноміальною залежністю п'ятого порядку з коефріцієнтам достовірності, який змінюється від 0,9924 до 0,9987 при проведення замірів в період перед збиранням основної продукції сільськогосподарських культур.

Відображення результатів дослідження і моделювання математичних залежностей зміни твердості ґрунту в залежності від глибини для реалізації різних варіантів технологічного процесу обробітку ґрунту під сільськогосподарські культури проводилось в програмному пакеті Microsoft Office (Excel).

Аналізуючи отримані результати, можна стверджувати, що параметр, який досліджувався, описується рівнянням поліноміальної залежності порядку виду:

$$
y=a x^{5}+b x^{4}+c x^{3}+d x^{2}+e x+i
$$

де: $y$-срункція (твердість ґрунту, мПа); $a, b, c, d, e-$ коефіцієнти регресії; $i$-вільний член регресії, $x$-аргумент (глибина обробітку, см).

\section{Висновки:}

1. Вибір способів обробітку ґрунту і його мінімалізація під сільськогосподарські культури дає 
можливість скорочення матеріальних і витрат енергетичних ресурсів.

2. Вибір способу обробітку ґрунту повинен спиратися на систему якісних показників властивостей ґрунту, які обумовлюються вимогами рослин до умов росту і розвитку в системі технологій виробництва основної продукції сільськогосподарських культур.

3. Моделювання математичних залежностей зміни показників твердості ґрунту і витрат палива повинно базуватися на виробничих умовах та вимогах до технологічних операцій, які відтворюють взаємопов'язані фрактори технологій вирощування сільськогосподарських культур.

\section{Література}

1. Танчик С. П. Плуг не відміняється. / Семен Петрович Танчик. // Пропозиція. - 2010. - №12. C. $76-77$.

2. Сайко В. Ф. Системи обробітку ґрунту в Україні / В. Ф. Сайко, А. М. Малієнко. - Київ: ТОВ ВД "ЕKMO", 2007. - 42 c.

3. Ресурсозберігаючі технології механічного обробітку ґрунту в сучасному землеробстві України / [І. Д. Примак, В. О. Єщенко, Ю. П. Манько та ін.]. - Київ: КВІЦ, 2007. - 272 с.

4. Механіко-технологічні властивості сільськогосподарських матеріалів: Підручник / [О. М. Царенко, Д. Г. Войтюк, В. М. Швайко та ін]. - Київ.: Мета, 2003. - 448 с.

5. Барабаш Г. І. Ефективність роботи грунтообробних машинних агрегатів при вирощуванні цукрових буряків / Г. І. Барабаш, О.В.Таценко // Вісник Сумського національного аграрного ун-ту: науковий журнал. - Серія «Механізація і автоматизація виробничих процесів» / Сумський НАУ. Суми, 2010. - Вип. 2(22). - С. 31-38.

6. Таценко О. В. Дослідження та моделювання залежності зміни твердості ґрунту в різних видах обробітку під цукрові буряки в умовах Сумщини / Олександр Володимирович Таценко // Вісник Сумського національного аграрного ун-ту: науковий журнал. - Серія «Механізація і автоматизація виробничих процесів» / Сумський НАУ. Суми, 2019. - Вип. 3 (37). - С. 25-30.

7. Таценко О. В. Вплив виду обробітку ґрунту на урожайність продукції цукрових буряків для умов лівобережного Лісостепу України / Олександр Володимирович Таценко // Вісник Сумського національного аграрного ун-ту: науковий журнал. - Серія «Механізація і автоматизація виробничих процесів» / Сумський НАУ. - Суми, 2016. - Вип. 3 (28). - С. 114-118.

8. Таценко О. В. Дослідження енергетичних витрат для обробітку ґрунту під цукрові буряки в лівобережному Лісостепі / Олександр Володимирович Таценко // Вісник Сумського національного аграрного ун-ту: науковий журнал. - Серія «Механізація і автоматизація виробничих процесів» / Сумський НАУ. - Суми, 2013. - Вип. 10 (25). C. $90-94$

9. Бахрушин В.Є. Математичне моделювання: Навчальний посібник / Володимир Євгенович Бахрушин. - Запоріжжя: ГУ "ЗІДМУ", 2004. $140 \mathrm{c}$.

10. Томашевский В.Н. Решение практических задач методами компьютерного моделирования / В.Н. Томашевский, Е.Г. Жданова, А.А. Жолдаков. - Киев: Изд-во "Корнійчук", 2001. - 268 с.

\section{References}

1. Tanchyk S. P. (2010) "Plug ne vidminiaietsia", Propozytsiia, vol. 12, pp. 76-77.

2. Saiko, V. F. and Maliienko, A. M. (2007), Systemy obrobitku gruntu $v$ Ukraini [Tillage systems in Ukraine], TOV VD "EKMO", Kyiv, Ukraina.

3. Prymak, I. D., Yeshchenko, V. O., Manko, Yu. P. and in. (2007), Resursozberihaiuchi tekhnolohii mekhanichnoho obrobitku gruntu $v$ suchasnomu zemlerobstvi Ukrainy [Resource-saving technologies mechanical tillage in modern agriculture of Ukraine], KVITs, Kyiv, Ukraina.

4. Tsarenko, O. M., Voitiuk, D. H., Shvaiko, V. M. and in. (2003), Mekhaniko-tekhnolohichni vlastyvosti silskohospodarskykh materialiv [Mechanical and technological properties of agricultural materials], Meta, Kyiv, Ukraina.

5. Barabash, H. I. and Tatsenko, O. V. (2010), "Efektyvnist roboty hruntoobrobnykh mashynnykh ahrehativ pry vyroshchuvanni tsukrovykh buriakiv", Visnyk Sumskoho natsionalnoho ahrarnoho un-tu: naukovyi zhurnal, seriia Mekhanizatsiia $i$ avtomatyzatsiia vyrobnychykh protsesiv, no. 2(22), pp. 31-38.

6. Tatsenko, O. V. (2019), "Doslidzhennia ta modeliuvannia zalezhnosti zminy tverdosti gruntu $\mathrm{v}$ riznykh vydakh obrobitku pid tsukrovi buriaky v umovakh Sumshchyny", Visnyk Sumskoho natsionalnoho ahrarnoho un-tu: naukovyi zhurnal, seriia Mekhanizatsiia $i$ avtomatyzatsiia vyrobnychykh protsesiv, vol. 3(37), pp. 25-30.

7. Tatsenko, O. V. (2016), "Vplyv vydu obrobitku gruntu na urozhainist produktsii tsukrovykh buriakiv dlia umov livoberezhnoho Lisostepu Ukrainy", Visnyk Sumskoho natsionalnoho ahrarnoho un-tu: naukovyi zhurnal, seriia Mekhanizatsiia i avtomatyzatsiia vyrobnychykh protsesiv, no. 3(28), pp. 114-118.

8. Tatsenko, O. V. (2013), "Doslidzhennia enerhetychnykh vytrat dlia obrobitku gruntu pid tsukrovi buriaky v livoberezhnomu Lisostepi", Visnyk Sumskoho natsionalnoho ahrarnoho un-tu: naukovyi zhurnal, seriia Mekhanizatsiia $i$ avtomatyzatsiia vyrobnychykh protsesiv, no. 10(25), pp. 90-94. 
9. Bakhrushyn, V.Ye. (2004), Matematychne modeliuvannia: Navchalnyi posibnyk [Mathematical modeling: Textbook], HU "ZIDMU", Zaporizhzhia, Ukraina.

10. Tomashevskyi, V. N., Zhdanova, E. H. and
Zholdakov, A. A. (2001), Reshenye praktycheskykh zadach metodamy kompiuternoho modelyrovanyia [The solution of practical problems by computer simulation methods], Yzd-vo "Korniichuk", Kyev, Ukrayna.

\section{Аннотация}

\section{Исследование и моделирование показателей в различных видах обработки почвы под сельскохозяйственные культуры для условий черноземных почв Украины}

\section{А.В. Таценко, А.В. Мартинюк, В.С. Курской}

В технологиях выращивания сельскохозяйственных культур наибольшие резервы энергосбережения и повышения продуктивности сельскохозяйственных культур имеют способы обработки почвы. Современные тенденции сельскохозяйственного производства требуют обоснования, внедрения и использования рациональных современных почвообрабатывающих орудий и совершенствования существующих технологических процессов обработки почвы.

Проанализированы последние исследования и публикации направлений повышения эфффективности обработки почвы под сельскохозяйственные культуры и использования технических средств для их реализации в условиях черноземных почв Украины.

Проведены научные исследования и моделирование изменения показателя твердости почвы и энергетических затрат в различных способах и видах обработки почвы под сельскохозяйственные культуры для условий черноземных почв Украины. Процесс исследования и моделирования энергетических затрат и твердости почвы проводился на основе изменения показателей глубины обработки, вида обработки и типа технических средств, которые реализуют технологический процесс обработки почвы под сельскохозяйственные культуры.

В статье приведены результаты исследования влияния технологических процессов обработки на энергетические затраты и твердость почвы в условиях стационарного опыта исследовательского поля для различных вариантов обработки в технологиях выращивания сельскохозяйственных культур.

При исследованиях, которые проводились в соответствии с разработанной программой и методикой, определялись показатели качества выполнения процесса обработки почвы и расхода топлива в зависимости от вида и глубины обработки.

Моделирование математических зависимостей изменения показателей исследовались в 3D проекциях. Реализация 3D моделирования для различных вариантов технологического процесса обработки почвы под сельскохозяйственные культуры проводилось в программном пакете Statistica.

Изменение вида обработки и увеличения глубины обработки почвы обусловливает улучшение качества подготовки почвы и увеличение расхода топлива.

Ключевые слова: технологический процесс, обработка почвы, виды обработки почвы, технические средства, глубина обработки, твердость, расход топлива, исследования, моделирование.

\section{Abstract}

\section{The research and modeling indicators in different types of tillage soil under agricultural crops for the conditions black soil of Ukraine}

\section{O.V. Tatsenko, A.V. Martyniuk, V.S. Kurskoi}

In crop cultivation technologies, the greatest reserves reducing energy costs and increasing crop productivity are different types soil tillage. The current trends in agricultural production require substantiation, implementation and use of modern tillage technical means and improvement existing technological processes of tillage.

Are analyzed recent researches and publications of directions increase efficiency tillage soil for agricultural crops and use technical means for their realization in the conditions of black soil of Ukraine.

The are conducted scientific researches and modeling change of soil hardness index and energy costs in different types tillage soil for agricultural crops in the conditions black soil of Ukraine. The process of research and modeling energy costs and soil hardness was carried out on the basis changes in indices of cultivation 
depth, type tillage soil and type technical means that implement the technological process tillage soil under agricultural crops.

The article presents the results study the influence of technological processes tillage soil on energy costs and soil hardness in the conditions stationary experiment of the experimental field for different types tillage soil in technologies cultivation agricultural crops.

The research conducted in accordance with the developed program and methodology determined the quality of tillage soil and fuel consumption, depending on the type and depth tillage soil.

The modeling mathematical dependencies change of indicators was investigated in 3D projections. The implementation 3D modeling for various variants of the technological process of tillage soil under agricultural crops was carried out in the software package Statistica.

Changing the type soil tillage and increasing the depth of tillage causes improved soil preparation quality and increased fuel consumption.

Keywords: technological process, tillage soil, types of soil tillage, technical means, depth of tillage, soil hardness, fuel consumption, research, modeling

\section{Бібліографічне посилання/ Bibliography citation: Harvard}

Tatsenko O.V., Martyniuk A.V. and Kurskoi V.S. (2020) The research and modeling indicators in different types of tillage soil under agricultural crops for the conditions black soil of Ukraine. Engineering of nature management, (1(15), pp. 29 - 35.

Подано до редакції / Received: 12.01.2020 